\title{
Securitization and Chinese Climate Change Policy
}

\author{
Yan Bo ${ }^{1}$
}

Received: 5 September 2015/ Accepted: 15 December 2015/Published online: 24 February 2016

(C) Fudan University and Springer Science+Business Media Singapore 2016

\begin{abstract}
Purpose The efforts of the securitization of climate change have been witnessed since 2007 at both international and national level. While the effectiveness of those securitization efforts needs to be further assessed, the security implications of climate change have come to be recognized at both levels. In the above context, this article attempts to explore why China has not gone so far in the securitization of climate change, especially compared with the EU who acts as one of the securitizing actors?

Methods This study mainly applies the methods of case study and comparative analysis. It draws on securitization theory as developed by the Copenhagen School of Security Studies to assess climate securitization practice in a critical way, with China as a case and focus. It also compares the divergent views of China and the EU on international securitization of climate change and their different approaches.

Results China has been generally reluctant to climate change securitization at international level and has embraced the climate securitization at domestic level to a limited extent although it recognizes the security implications of this issue. The concerns of the political ramifications of the United Nations Security Council's involvement and different priority agenda could explain why China has not gone so far in the process of climate securitization.

Conclusion The awareness of the potential security implications of climate change has been increased since the UNSC's first debate on this topic in 2007. However, there are divergent views between China and other players on the question of whether it is appropriate to consider climate change a threat to international peace and security and whether the Security Council is an appropriate forum in which to consider climate change. Meanwhile, the EU and China have responded to climate security with a converging trend in terms of mitigation.
\end{abstract}

Yan Bo

boyan@fudan.edu.cn

1 Fudan University, Room 704, Wenke Building, Shanghai 200433, China 
Keywords Securitization theory - Climate security - Climate change policy · China $\cdot$ EU

\section{Introduction}

There is a consensus in international society that the urgency of taking more effective action on climate change should be heightened. This is reflected in the Paris Agreement adopted by 195 nations at the end of 2015 as an historic outcome of the United Nations Framework Convention on Climate Change (UNFCCC) process and aims to strengthen the ability to deal with the impacts of climate change. Except for the long-established multilateral negotiation process through which global climate agreements have been adopted and implemented, the efforts of the securitization of climate change have been witnessed since 2007 at both the international and national level. While the effectiveness of those securitization efforts needs to be further assessed, the security implications of climate change have come to be recognized at both levels. In the above context, this article attempts to explore why China has not gone so far in the securitization of climate change, especially compared with the EU who acts as one of the securitizing actors? Specifically, China has been generally reluctant to securitize climate change at an international level and has embraced climate securitization at the domestic level to a limited extent although it recognizes the security implications of this issue. These facts need to be explained for further understanding of China's climate change policy and enhancing the effectiveness of global climate policy.

This article draws on securitization theory as developed by the Copenhagen School of Security Studies to assess climate securitization at both the international and national level, with China as a focus. It consists of six sections. Section 2 gives some theoretical reflections on the applicability and limits of securitization theory, especially for the issue of climate change. Section 3 analyzes China's general reluctance to climate securitization at an international level and Sect. 4 considers China's limited climate securitization at a domestic level. The fifth section will explain why China has not gone so far in climate securitization and what its concerns are. Some assessment and policy implications will be given in the conclusion.

\section{Securitization and Climate Change: A Theoretical Reflection}

Associated with the Copenhagen School (Wæver 1995; Balzacq 2010; Buzan et al. 1998), securitization is the process whereby particular issues come to be conceived and approached as security threats to particular political communities, through a combination of speech acts and audience acceptance. Specifically, securitization shifts a given issue into another domain and enables emergency measures to deal with that issue if supported by a relevant audience. The securitization framework emerged in the context of growing calls to broaden the scope of security to include a 
range of non-military threats and it potentially allows for the inclusion of issues such as environmental change as security issues (McDonald 2012).

Climate change can be seen as a typical issue to test the applicability and limits of securitization framework. First of all, it is one of the most significant issues on the global and national agenda with increasing security implications. Secondly, there is a big gap between established global climate governance efforts and the target of preventing global average temperature from rising $2{ }^{\circ} \mathrm{C}$ higher than the preindustrial level. Thirdly, there are already some securitizing moves of climate change at both global and national levels, which provide the empirical basis for further reflections. From a theoretical perspective, the following four aspects need to be further considered with the application of securitization framework to the issue of climate change.

\subsection{The Referent Object of Security and Emergency Measures}

In developing the securitization framework, Buzan et al. (1998) noted the particular challenges associated with the securitization of environmental issues. These challenges are regarding what constitutes the referent object of security, and what actions might constitute emergency measures following representations of threat.

Although securitization theory emphasizes the diversity of the referent object of security, it is a fact that the sovereign state is still the basic unit and actor in current international society. In view of responsibilities and capabilities, global environmental issues have to be approached mainly from the perspective of the state that faces different sources of threats. In this given condition, the rules of securitization at international and domestic levels will be different since there are different political actors, audiences and measures at the above two levels. Some empirical study of different scenarios of climate securitization in world politics and at the national level further prove this (Scott 2012; Mcdonald 2012). Therefore, the distinction between international securitization and domestic securitization in both theory and practice is a necessity.

The theorists of securitization have not specified "emergency measures" but imply that emergence measures are the legitimate outcome of a given issue being taken out of normal political process. Therefore, it is generally recognized that military mobilization is the clearest indicator of emergency measures. In Europe's social and political context, political and security areas are relatively distinguished. However, the securitization theory lacks explanatory power in Asia's social and political context since securitization cannot draw a clear line around certain issues (such as migration) which are very complicated, uncertain and even controversial themselves. In Asia, the securitization of certain issues was conducted in the routine political process instead of outside political procedure (Caballero-Anthony et al. 2006).

Moreover, scholars have long questioned whether armed forces are capable of meeting the challenges posed by environmental change. Some scholars argue against the idea that climate change in particular should be met with a militarized response: "The problems are too broadly distributed and the consequences are too deeply penetrating for such an approach to be successful', (Liotta and Shearer 2007: 
133). If climate change requires a behavioral shift to achieve lasting solutions, then narrowly defined militarized solutions are unlikely to be sufficient responses (Detraz and Betsill 2009: 314).

\subsection{The Indicator(s) of Assessing Securitization}

How do we know when the securitization of a certain issue is accomplished? Securitization theory's ambiguities over this question cause analytical confusion among researchers who apply the theory to empirical study.

There are numerous debates regarding the weight that should be attached to language, audience acceptance and exceptional measures in making sense of the process of securitization (McDonald 2008, 2012; Balzacq 2005, 2010; Roe 2008; Salter 2010; Stritzel 2007). Some researchers have focused exclusively on the language of security, "with the material practices following from this language either assumed or ignored" (Mcdonald 2012; Mazo 2010; Gad and Petersen 2011). Therefore, they use the language of climate security as evidence of climate securitization. For example, some analysts cite examples of the United Nations Security Council discussion of climate change in 2007 and the inclusion of climate change as a 'threat' in a range of National Security Statements to demonstrate securitization (Dupont 2008; Mazo 2010).

Other analysts draw more attention to the role of audience acceptance and emergency measures in the process of securitization of climate change (McDonald 2012). Wæver's analysis indicates that a referent object has not been fully securitized until it has been moved out of 'ordinary', 'democratic' politics to be dealt with as a matter of urgency in emergency mode. This can only happen if certain facilitating conditions have been met, including that the relevant 'audience' has accepted the 'securitizing move' (Buzan and Wilde 2008: 31-33). Translated into the international arena in the field of climate change, full securitization would seem to be represented by the issue moving outside of the normal multilateral treaty framework to the United Nations Security Council with 'primary responsibility for the maintenance of international peace and security' (Scott 2012). At the national level, full securitization would seem to be represented by the issue moving outside of the normal political process to the body of security institutions and military.

\subsection{The Conditions of Securitization}

The Copenhagen School has not articulated the conditions under which a referent object could be successfully securitized. Why are some issues more difficult to be securitized than others? What are the relevant factors influencing securitization? The below provide four points, taking climate change as a case.

Firstly, the nature of the issue matters. Although the securitization framework is open to the inclusion of 'nontraditional' security issues, some nontraditional security issues are more urgent than others in their nature. One of the problems to understanding the security implications of climate change is that the climate issue is different than most other issues defined as non-traditional security issues. Climate change is a more abstract phenomenon than many other environmental issues and 
will be experienced in different ways. While there is some variation in the time horizon expected for climate change, the pace will be relatively slow but the impact will spread to a variety of arenas, including water availability, food availability, and so on (Detraz and Betsill 2009). If extreme weather events justify the necessity of emergency measures, the potential risks in the long-time frame of 30, 50 or 100 years would question the relevance of emergence measures.

Secondly, in order to legitimate emergency measures, the securitizing actors have to show how convincing the existent threats are and what the causal mechanism is. In the field of climate change, many literatures or practices have built the connection between climate change and the outbreak of violent conflict. However, a casual logic has not yet built in a pervasive way, which should be used as the basis of eliminating an alternative solution and specifying the responsible actors and victims. In addition, the moral logic is also indispensable to justify the proper position of securitization by claiming certain behavior as moral needs while opposing immoral behavior.

Thirdly, the political ramifications of securitization should be acceptable to both the securitizing actors and audience. If the securitization of an issue collides with some prevailing principles or causes new threats or risks (including the inference of domestic affairs or the violation of sovereignty), it is impossible to be successful. For example, if the introduction of conflict concerns into the international climate change debate and securitizing moves in Security Council cause the political concerns of certain countries, it might create tensions among countries, which form political hurdles to the securitization of climate change.

Fourthly, different priority agendas would influence the process of securitization. The Copenhagen school is Eurocentric in identifying the threat of non-traditional security issues and its theory of securitization is mainly based on European history and culture. However, most developing countries in other parts of the world are facing more priorities in their agenda including development, the eradication of poverty and improving the populace's livelihood. Although they share some concerns with European countries toward climate change, their priorities are not totally the same since they have different national circumstances and stay at different development stages. Therefore, different priority agendas will influence their motivations of securitizing certain issues.

\subsection{The Effectiveness of Securitization}

In the most basic sense, securitization involves referring to an issue that has been conceptualized in political, economic, environmental or other terms as a security threat so as to heighten awareness of the issue and the urgency of taking effective action (Scott 2012: 221). However, the Copenhagen School has not drawn much attention to the assessment of the effectiveness of securitization. Proponents of securitization have to assess to what extent the securitization of an issue contributes to the solution of the issue. Otherwise, the relevance of the securitization to the strategies and policies for coping with nontraditional security issues would be doubtful.

A security dialogue is an understandable choice for those who wish to raise the profile of climate change on the global and national agenda. Many scholars and 
policy makers are convinced of the security implications of climate change. At the same time, there are others who question whether framing climate change as a security issue is beneficial. Therefore, the following indicator could be used to assess the effectiveness of securitizing moves of climate change at both an international and national level: Do the securitizing moves of climate change advance international and national efforts to address climate change?

\section{China's General Reluctance to International Securitization of Climate Change}

There are three major securitizing moves of climate change at the international level. The United Nations Security Council held its first ever debate on the impact of climate change on security on April 17, 2007. The session was chaired by British Foreign Secretary, Margaret Beckett. Warning of migration on an unprecedented scale because of flooding, disease and famine, she said that climate change was a security issue, but it was not a matter of narrow national security... it was about "our collective security in a fragile and increasingly interdependent world". SecretaryGeneral Ban Ki-moon said that projected climate changes could not only have serious environmental, social and economic implications, but implications for peace and security, as well. He called for a "long-term global response" to deal with climate change, along with unified efforts involving the Security Council, Member States and other international bodies. ${ }^{2}$

While some speakers praised the initiative, there were reservations from developing countries, which saw climate change as a socio-economic development issue to be dealt with by the more widely representative General Assembly. ${ }^{3}$ China's representative emphasized that climate change could have certain security implications, but, generally speaking, it is, in essence, an issue of sustainable development. He argued that the Security Council was not the proper forum for a debate on climate change since "the developing countries believe that the Security Council has neither the professional competence in handling climate change-nor is it the right decision-making place for extensive participation leading up to widely acceptable proposals". ${ }^{4}$ According to him, "Discussing the issue in the Security Council would not help countries in their efforts, and it would be hard for the Council to assist developing countries affected by climate change to find more effective adaptations. It would not help produce widely acceptable proposals". He added "discussions in today's meeting should be regarded as an exception, with neither outcome documents, nor follow-up actions. ${ }^{5}$

\footnotetext{
${ }^{1}$ Security Council holds first-ever debate on impact of climate change on peace, security, hearing over 50 speakers. http://www.un.org/press/en/2007/sc9000.doc.htm.

2 Ibid.

${ }^{3}$ Ibid.

${ }^{4}$ Ibid.

5 Ibid.
} 
Meanwhile, China holds that it was necessary to follow the principles set forth in UNFCCC, respect existing arrangements, strengthen cooperation and encourage more action to effectively respond to climate change. China supported conducting full and pragmatic discussions on related issues within the mechanisms of the UNFCCC. ${ }^{6}$

The second securitizing move of climate change at the international level was mainly initiated by a coalition of the Pacific Small Island Developing States and General Assembly which held its first debate on climate change security in 2009. On 3 June 2009, the General Assembly passed Resolution 63/281 in which it acknowledged that the impacts of climate change could have possible security implications while at the same time reaffirming the UNFCCC as the key instrument for addressing climate change. ${ }^{7}$ Resolution 63/281 invited the relevant organs of the United Nations, 'as appropriate and within their respective mandates, to intensify their efforts in considering and addressing climate change, including its possible security implications'. It also requested the Secretary-General to submit a comprehensive report to the General Assembly on the possible security implications of climate change. ${ }^{9}$

On behalf of the Pacific Small Island Developing States, Nauru's representative emphasized that rising oceans could, sooner than previously thought, leave little of that regional group's already tiny homelands above water unless urgent action was taken. She stressed the impact of climate change included inundation of heavily populated coastal areas, loss of freshwater, failure of agriculture and other results of saltwater intrusion. As a result, resettlement and migration were already occurring and dangers to international peace and security would soon increase. ${ }^{10}$

China joined the representatives of developing countries, including Indonesia Bahrain and Argentina. Brazil stressed that the resolution must not undermine the primary responsibility of the General Assembly, and in some areas the Economic and Social Council, both of which must address climate change from the viewpoint of sustainable development and the eradication of poverty. ${ }^{11}$ They said UNFCCC should provide the outline for action on the issue, urging all States to fulfil their commitments under that instrument, particularly the industrialized nations that generated most greenhouse gases, while developing countries were the most threatened. ${ }^{12}$ Although China were more relaxed with the debate on climate change security in General Assembly than in UNSC, it still emphasized that climate change should be approached as a sustainable development issue and UNFCCC should be the basic institution.

\footnotetext{
6 Ibid.

7 Climate change and its possible security implications (UNGA Resolution A/RES/63/281, 3 June 2009).

8 Ibid., at paragraph 1.

9 Ibid., at paragraph 2.

${ }^{10}$ General Assembly, expressing deep concern, invites major united nations organs to intensify efforts in addressing security implications of climate change. http://www.un.org/press/en/2009/ga10830.doc.htm.

11 Ibid.

12 Ibid.
} 
The Security Council held its second debate on "Maintenance of international peace and security: the impact of climate change" in July 2011, under German leadership. Germany said consideration of the security implications of climate change was consistent with the Council's mandate to maintain international peace and security. Citing the 2009 Report of the UN Secretary-General (A/64/350), Germany also highlighted the "ultimate security threat" of sea-level rise for some small island States, and the related potential consequences of forced migration and social and political tensions, which could derail efforts in peacebuilding and postconflict stabilization. ${ }^{13}$ Apparently, Germany proposed the involvement of UNSC in climate change by framing it as a security threat and stressing the consequences of "tensions" and "conflict".

Approximately 65 speakers took the floor during the debate, presenting opposing views over the question posed by Germany-how the Council could address such scenarios within its mandate. One notable feature of the debate was the shift in the stance adopted by the United States, which had made little substantive contribution to the 2007 debate. US Ambassador Susan Rice was highly supportive, both in terms of acceptance of climate change as a threat to international peace and security and of the appropriateness of the issue being addressed by the Security Council (Scott 2012). Speaking on behalf of the Pacific small island developing States, the Maldives, Seychelles and Timor-Leste, Marcus Stephen, President of Nauru, called on the Council to demonstrate its solidarity with the Pacific 'by formally recognizing that climate change is a threat to international peace and security'. ${ }^{14}$

In contrast, the Group of 77 and the Non-aligned Movement remained reluctant to accept that climate change is usefully seen as a security threat and did not accept a role for the Security Council on the matter. Developing countries continued to maintain that climate change needs to be discussed in terms of sustainable development. They regarded the move to discuss it in terms of international security as an attempt by developed countries to shirk their international development commitments and to avoid ambitious emissions reductions (Scott 2012). China, among others, outlined its objections to considering climate change within the Security Council. China reiterated that climate change could affect security, but it was fundamentally a sustainable development issue, which the Council did not have the means and resources to address. ${ }^{15}$ China also maintains that the international community should adopt effective measures to help Small Island developing States, especially by giving them capital, technology and capacity-building support. ${ }^{16}$

As in 2007, the Security Council did not make a decision on climate change after the day-long debate. However, it concluded with a Presidential statement, a nonlegally binding document adopted by consensus. This statement expressed concern at the possible security implications of loss of territory of some states caused by sea-

\footnotetext{
13 Ibid.

14 Security Council, in statement, says 'contextual information' on possible security implications of climate change important when climate impacts drive conflict, 20 July 2011. http://www.un.org/press/en/ 2011/sc10332.doc.htm.

15 Ibid.

16 Ibid.
} 
level rise-particularly in small low-lying island States. It recognizes the responsibility for climate change and other sustainable development issues conferred upon the General Assembly and ECOSOC, and underlining the Assembly's 2009 resolution reaffirming the UNFCCC as the key instrument for addressing climate change. ${ }^{17}$ The statement also noted that "conflict analysis and contextual information" on the "possible security implications of climate change," inter alia, is important when climate issues drive conflict, challenge implementation of Council mandates or endanger peace processes. The Council therefore asked the UN Secretary-General to ensure that his reporting to the Council contains such contextual information. ${ }^{18}$

From above, European countries, especially the UK and Germany took a leading role in advocating both that climate change is appropriately referred to in terms of security and that the Security Council should be part of the global response. This was joined by the leaders of small island countries, the US and international organizations. UN Secretary-General Ban Ki-moon asserted in 2007 and 2011 that a Security Council debate on climate change was appropriate and essential. He said climate change "not only exacerbates threats to international peace and security, it is a threat to international peace and security," and that members of the Council have a "unique responsibility" to mobilize action to confront the threats posed by climate changes to international peace and security. ${ }^{19}$ Achim Steiner, Executive Director of the UN Environment Programme (UNEP), said climate change acts as a "multiplier" to existing threats including competition over water and land. He argued that sea-level rise represents a key threat to security. ${ }^{20}$ The above have played the role of securitizing actors.

Although China recognized the security implications of climate change, it, among other developing countries has been generally reluctant to accept international securitization of climate change which frames it as an international security issue and proposes the involvement of UNSC. Applying the securitization framework, China has played the role of audience in the process which did not accept the logic of climate securitization given by the securitizing actors. Moreover, China maintains that climate change should be conceived and approached primarily as a development issue. Accordingly, it insists on the central role of UNFCCC as the major institution addressing global climate change.

Wæver (2007) once observed that climate change has been depicted as a security threat at the international level, and these articulations have been broadly endorsed in an international context (for example, in the language of the UNFCCC process), but emergency measures have not flowed from that 'successful' securitization. For Wæver, international climate securitization is a case of 'all dressed up and nowhere

\footnotetext{
${ }^{17}$ UN Security Council debates security impacts of climate change. http://climate-1.iisd.org/news/unsecurity-council-debates-security-impacts-of-climate-change/.

18 Ibid.

19 Security Council, in statement, says 'contextual information' on possible security implications of climate change important when climate impacts drive conflict, July 2011. http://www.un.org/press/en/ 2011/sc10332.doc.htm.

${ }^{20}$ UN Security Council debates security impacts of climate change. http://climate-1.iisd.org/news/unsecurity-council-debates-security-impacts-of-climate-change/.
} 
to go' (McDonald 2012). But it might be too early for him to have said in 2007 that climate change is successfully securitized at the international level. Even more recently, the notion of climate security at the international level has just received patchy support which ultimately limits the possibility for an institutionalized role of the UNSC as a climate security provider. The absence of emergency measures further implies that international securitization of climate change stays at a preliminary stage.

\section{China's Limited Embrace of Domestic Securitization of Climate Change}

China's perception of climate change as a security concern has emerged and developed since 2007 at the domestic level. Before that, China used the word "impact" to describe the adverse effect of climate change. For example, China's 2007 National Climate Change Programme says: 'Studies indicate that climate change has caused some impacts on China, such as sea level rise in the coastal areas, glacial retreat in northwest area, the earlier arrival of the Spring phenophase. It will also bring about significant impacts on China's natural ecosystems and social economic system in the future' (Information Office of the State Council 2007).

Witnessing more frequent and increasingly prominent extreme weather events worldwide and especially in its homeland in the year 2008 (National Development and Reform Commission (NDRC) 2009) and highly identifying the IPCC report issued in 2007, China has begun to be more deeply cognizant of the threat of climate change. In the White Paper on climate change published in 2008, China began to use the term 'threat' instead of 'impact' when talking about the adverse effects of climate change. It says: 'China is vulnerable to the adverse effects of climate change, which has posed substantial threats to the natural ecological systems as well as the economic and social development of the country. These threats are particularly pressing in the fields of agriculture and animal husbandry, forestry, natural ecological systems and water resources, and in coastal and ecological fragile zones' (Information Office of the State Council 2008).

Moreover, climate change first appeared in the White Paper of China's National Defense in 2008, which mentioned that issues such as terrorism, environmental disasters, climate change, serious epidemics, transnational crime and pirates are becoming increasingly prominent' (Information Office of the State Council 2009). China subsequently stated in its 2010 White Paper on National Defense that: 'Security threats posed by such global challenges as terrorism, economic insecurity, climate change, nuclear proliferation, insecurity of information, natural disasters, public health concerns and transnational crime are on the rise' (Information Office of the State Council 2011). This was a strong statement on the security implications of climate change and from this language and its setting, we can see that China began to define climate change as a security issue. But apparently, China identified climate change as a security threat after other extended discussion of the threats posed to China, including terrorism and economic insecurity. Climate change was 
therefore not at the forefront of China's discussion of security. Climate change is just one of the (new) non-traditional security issues for China.

According to the Meteorological Administration of China's General Staff, the increasing extreme weather events in recent years have threatened the security of military personnel and facility, affecting the effectiveness of weapon equipment and military operations, which restricts the formation and improvement of the combat effectiveness of troops. ${ }^{21}$ Moreover, the continual rise of sea levels caused by climate change directly affects the strategic deployment of islands and coastal areas and the construction of the battlefield. Zhanghaibin, an IR professor in Beijing University argued in his book published in 2010, climate change is a national security issue, in terms of four aspects of threats: the rise of seal levels caused by climate change leading to the reduction of China's land area and the degradation of land quality (desertification); climate change adversely affecting the Chinese people's livelihood (including the impact of freshwater resources and food production, threatening Chinese people's lives and properties); climate change adversely affecting China's major national defense and strategic projects and military construction; the adverse impact of taking on international climate commitments on its sovereignty (future development space and independent choice) (Zhang 2010). In general, the threats of climate change to China's national security, including military personnel, facilities and military operations, have been recognized both in government and academia. However, the relations between climate change and conflicts have not been explicitly built, at least in public policy and works.

Two developments promote the use of "climate security" as a term in China since 2014. Chinese President Xi Jinping articulated in May 2014 that China defines security in a comprehensive way, which includes political security, homeland security, military security, economic security, cultural security, social security, science-technology security, cyber security, biological security, resource security, and nuclear security. To implement comprehensive national security, China not only pays attention to external security, but also attaches importance to internal security; not only traditional security, but also non-traditional security. In November of the same year, IPCC adopted its Fifth Assessment Report (AR5), according to which global climate change will further enlarge the risks to natural ecosystems and human society and will generate new risks.

In the context of a comprehensive approach adopted to national security and highly identifying the conclusion of AR5, China Meteorological Administration (CMA), among other ministries is most vocal in articulating the term of "climate security". ZHENG Guoguang, the Administer of China Meteorological Administration, said in an article published in People's Daily in 2014, "climate change has already proposed severe challenges to China's national security" since it has already affected China's natural ecological system and social system and will propose severe threat to China's traditional and non-traditional security, including food security, water resource security, ecological security, environmental security,

\footnotetext{
${ }^{21}$ China sets up Military Climate Change Expert Committee. December, 2008. http://news.xinhuanet. com/newscenter/2008-11/07/content_10323151.htm.
} 
energy security, major projects security and economic security (Zheng 2014b). According to him, climate security is the status that the survival and development of human society is free from the threat of climate change. As a new non-traditional security, climate security is an important prerequisite for China's food security, water resources security, ecological security and other security of the national security system. He stressed that climate security is the basic needs of building a resource-saving and environment-friendly society and the important basis for addressing climate change and disaster prevention and mitigation as well as the basic guarantee of the construction of ecological civilization and the realization of the "Chinese dream" (Zheng 2015). This proposal was echoed by Zhang Haibin who proposes that China should not only integrate climate change into its economy and social development planning but also into the framework of comprehensive national security since eight out of eleven types of national security have been already threatened by climate change (Zhang 2015). For both of them, climate change should be securitized in, not outside of, the normal political process in China.

From above, the security implications of climate change have been more clearly articulated in China and "climate security" has become a more explicitly used language especially by the CMA. But CMA's frequent use of climate security since 2014 has not gained much resonance from other departments, especially NDRC which is the leading unit of China's climate issues and holds that climate change is primarily a development issue. There is neither public debate between the two speech acts. Even CMA itself maintains that climate change is both a development issue and a security issue (Zheng 2015).

The Chinese military appeared more cognizant of the many challenges with which they would likely be faced in the field of climate change. A Military Climate Change Expert Committee was set up in December 7, 2008, aiming to provide technical support for the military to address climate change and effective guidance for the military's warfare and disaster management training and anti-disaster preparedness. The General Logistics Department also held its first report meeting on "Military response to climate change" in 2013 to focus on the impact of climate change on military activities and spread the knowledge of reducing meteorological and hydrological disasters. However, the Chinese Military's public pronouncements and actions to date have been limited to disaster prevention and relief and resource and energy saving although it has already conceived the impact of climate change on defense and military building, the development of equipment and military maneuvers. The Chinese military and Chinese Defense Department has neither formulated the strategy of "mitigation and adaptation" in its strategic planning, which is in contrast with the militaries of the US and UK. In general, climate change has not been a priority for the military. Moreover, although the leading group of climate change in China has been enlarged in 2008 and adjusted in 2013, the military has not been the participating unit yet and NDRC has still played the coordinating and leading roles among nearly 20 departments at the central level. Therefore, the military's roles are rather limited in climate change in China.

Meanwhile, even relatively mainstream political and economic responses to climate change instead of emergency measures were witnessed in China's climate 
security policy system, especially in mitigation and adaptation. China announced in 2009 that it would voluntarily reduce its carbon dioxide emission per unit of GDP in 2020 by $40-45 \%$ compared with the 2005 level. It is the first time for China to set a domestic legally binding target for reducing carbon dioxide. The Twelfth Five-Year Plan for National Economic and Social Development, approved in 2011, integrates measures for addressing it into the country's mid-term and long-term plans for economic and social development. It sets binding targets to reduce energy consumption per unit of GDP by $16 \%$, cut $\mathrm{CO}_{2}$ emissions per unit of GDP by $17 \%$, and raise the proportion of non-fossil fuels in the overall primary energy mix to $11.4 \%$. China submitted its Intended Nationally Determined Contributions to the UNFCCC in June 2015, which set three targets: for $\mathrm{CO}_{2}$ emissions to peak by 2030 or earlier, to increase the non-fossil share of China's primary energy to around $20 \%$ by 2030 , and to reduce the economy's carbon intensity by $60-65 \%$ by 2030 compared to 2005 levels. China is determined to embrace the mitigation approach to achieve absolute reduction of emissions even in the face of economic downturn which shows its increasing political will. To adapt to climate change, China issued its National Strategy for Climate Change Adaptation in November 2013, laying out guidelines, principles and goals for climate change adaptation and a wide range of measures to be implemented by 2020, including early-warning detection and information-sharing mechanisms at the national and provincial levels, ocean disaster monitoring system and coastal restoration (NDRC 2013).

\section{Explaining China's Moves and Policies}

China's general reluctance to international securitization of climate change and limited embrace of climate securitization at the domestic level deserve further explanation. We offer the following four considerations.

First of all, although China and other actors like the EU have recognized the security implications of climate change and share climate security representation, they differ in identifying what the specific threats arising from climate change are.

The EU emphasizes the conflict multiplier implications of climate security, although it is also deeply concerned with the "non-conflict" threat of climate change. For example, the first of the threats from climate change listed for consideration by the European Council was the potential for conflict over resources. ${ }^{22}$ In contrast, China focuses on the more convincing and urgent impact of climate change on its development. China emphasizes the threat of climate change on the national natural ecosystem and social system as well as the adverse impact on other elements of its national security such as economic security and food security. Even CMA argues that climate security should focus on extreme climate events and disasters related to agriculture, increased risks of water resources, ecological security and people's health (Zheng 2014a, b, 2015). China has not identified with the conflict implications of climate security at both the international

\footnotetext{
${ }^{22}$ The European Council released a paper on climate change and international security in May 2008, which provided a useful summary of seven threats deemed likely to emanate from climate change.
} 
and domestic level, at least in public statement and policies. Moreover, China holds that climate security is embedded in its homeland security while the EU emphasizes climate security as a multilateral issue.

Accordingly, While China shares with the EU that climate security policy includes mitigation and adaptation efforts, development and humanitarian aid programmes, China is generally reluctant in its linkage with conflict prevention or solution and to considering the Council to be the appropriate forum in which to address climate change at the international level. At a domestic level, Chinese military has played limited roles in the field of climate change except on meteorological disaster rescue and relief.

Secondly, China is deeply concerned with the political ramification of climate securitization at the international level, especially with the involvement of UNSC.

When climate change was debated in the UNSC in April 2008 and July 2011, the Chinese representative rejected the idea that the Security Council should consider climate change. China's representatives in the UNSC discussion revealed its basic concerns, namely accepting climate change as a security issue at an international level and involving UNSC might be used as justification for western military interventions in domestic affairs and the potential for the Council to oversee the implementation of mandatory measures to address climate change. These potential scenarios go against the principles of non-interference in internal affairs and sovereignty that China cherishes very much since China holds that the state has sovereignty over both traditional and non-traditional security issues.

From Chinese representative's remarks, we can further infer that China is also concerned with the lack of universality and legitimacy of UNSC in addressing climate change. Therefore, China argues that discussions on climate change should be conducted within the framework that "allowed participation by all parties" and UNSC "did not allow extensive participation in decision-making" and would not help produce "widely acceptable proposals". ${ }^{23}$ China is also doubtful of the authority of the UNSC's potential involvement in climate change since it "did not have expertise". Finally, China is questioning the moral logic and ineffectiveness of UNSC potential involvement since "it would be hard for the Council to assist developing countries affected by climate change to find more effective adaptations". 24

China was not the only one to articulate the above concerns. According to some observation, the divisions within the 2007 debate largely echoed the broader political divide on climate change policy between North and South, with $70 \%$ of all Northern speakers supporting Security Council jurisdiction compared with only $29 \%$ of all Southern speakers (Detraz and Betsill 2009). All of the speakers arguing against Security Council involvement were from the South and seven of these speakers took the position that climate change was beyond the Security Council's narrow mandate (Detraz and Betsill 2009). Moreover, Egypt and India argued that Northern countries were trying to shirk their responsibilities for controlling

\footnotetext{
${ }^{23}$ Security Council holds first-ever debate on impact of climate change on peace, security, hearing over 50 speakers. http://www.un.org/press/en/2007/sc9000.doc.htm.

24 Ibid.
} 
greenhouse emissions and shift attention to the need to address potential climaterelated conflict in the South (Detraz and Betsill 2009).

Thirdly, China's different priority agenda makes itself distinct with other international actors in the securitization of climate change.

Although China increasingly conceives the threat from climate change and regards it as a non-traditional security issue, China perceives climate change primarily as a development issue, emphasizing that climate change arises out of development and should thus be solved along with development ( $\mathrm{Hu}$ 2012). Therefore, China emphasized that the international community "should give full consideration to developing countries' stage of development and specific needs and circumstances, and accordingly, give them the requisite assistance." Accordingly, for China, the Council's discussions should not substitute for UNFCCC negotiations and UNFCCC is the competent and legal regime at the international level of addressing climate change. At the national level, although climate security is more explicitly used by the CMA along with framing climate change as a development issue, the development issue discourse of climate change trumped climate security discourse in a general sense.

Moreover, non-traditional security issues have been endowed with different priority in China compared with the EU. While with the EU more attention has turned to a broad raft of nontraditional security concerns, China continues to rely on strictly applying the principle of sovereignty, linking it with the unification of the Chinese nation and territorial integrity. For China, nontraditional security concerns may indirectly threaten Chinese sovereignty via the link of development. China's emphasis on peaceful coexistence suggests a clear linkage between the protection of national sovereignty and Chinese growth and development. This becomes particularly evident in the case of terrorism and organized crime. Attending the Conference on Interaction and Confidence Building Measures in Asia in May 2014, the Chinese president $\mathrm{Xi}$ Jinping urged "zero tolerance" toward terrorism, extremism, and separatism, and also referred to the menace to the whole of Asia of organized crime and environmental disasters. While these statements demonstrate the importance China places on nontraditional security threats, nontraditional security issues have hitherto not received distinct recognition in Chinese security and defense strategy (Fanoulis and Kirchner 2015).

Fourthly, Chinese military's missions of coping with nontraditional security issues have been achieved within the political process instead of outside of it.

According to the Copenhagen School, the securitization of climate change has tendency to locate the authority for solutions and action in the military apparatus of states. But Chinese military had paid only scant attention to climate change compared with the EU and the US. Actually, climate change has not been mentioned specifically in the Defense White Papers issued in 2013 and 2015 and it seems that climate change has been classified as one of the non-traditional security issues. The General Staff of People's Liberation Army has set up expert commissions and specialized bodies to study potential national security consequences of climate change. But those studies have not led to authoritative statements from the army on the issue (Freeman 2010: 22). The limited treatment of climate 
change in security documents and lack of debate in the military are in line with official discourse of climate change.

Moreover, China's military's approach to the maintenance of nontraditional security is different from that of the EU. At a general level, its main missions in this field are defined as: counter-terrorism operations, maintenance of stability, disaster relief, maintenance of interests, security alert, international maintenance and military assistance (Li 2009). Due to the difference of non-traditional and traditional security issues, China holds that military generally take non-war military operations in the maintenance of non-traditional security and take acts of wars in the maintenance of traditional security. The war action emphasizes the role of military while the non-war military action emphasizes the dominant role of government and requires the use of military power to highlight joint consciousness. In the war, the army is often the main body of action, usually based on the military command system. The non-war military operation, which is a part of national administrative acts, is to complete periodic or regional tasks in the process of coping with the crisis. Therefore, in non-war military operations, the military needs to pay more attention to cooperation with the government departments, people, the media and even multinational forces while achieving joint command inside the military (Li 2009). These differences determines that China's military's involvement in climate change is inside of 'ordinary' political process.

Moreover, the Chinese military is also involved in the climate mitigation of the whole of society by saving resources and energy at the level of Barracks. The leading units of this campaign are General Logistics Department and NRDC with the supporting units of PLA Institute of logistics, Logistics Science Research Institute etc. ${ }^{25}$ But official documents give no suggestion the military might play such a role outside the country.

\section{Conclusions}

The awareness of potential security implications of climate change has been increased since the UNSC's first debate on this topic in 2007. However, this article reveals divergent views between China and other players on the question of whether it is appropriate to consider climate change a threat to international peace and security and whether the Security Council is an appropriate forum in which to consider climate change.

Securitizing actors at international levels stresses the conflict multiplier implications of climate change that is used as the main rationale for the involvement of UNSC. While climate change could contribute to armed conflict

\footnotetext{
25 To mobilize the enthusiasm of the whole society to participate in energy-saving and emission reduction, China's National Development and Reform Commission jointly with the Central Propaganda Department, the Ministry of Education, Ministry of Science and Technology etc. (17 departments altogether) issued the "The Whole Society Action Plan of Energy-saving and Emission Reduction during the Twelfth Five Year Plan" in January 31, 2012. It aims to guide ten special actions of energy-saving and emissions reduction involving family community, enterprises, schools, military camps, rural areas, government agencies, science and technology, the popularization of science and the media.
} 
and violence, that may not be the primary risks and there are many other risks that also need to be considered. Climate change is predicted to have immense impacts on much of the world's population, resulting in large-scale human security threats (Barnett and Adger 2007). Preventing large-scale humanitarian catastrophes from climate-related droughts, floods, crop failures, mass migrations, and exceptionally severe weather remain the most significant policy challenges (Purvis and Busby 2004: 72). A limited focus on conflict over resources ignores the wider security implications of climate change. Moreover, it would result in a narrowing of policy options focused on a particular form of adaptation-avoiding conflict_-and other adaptation and mitigation strategies for addressing those issues could be downplayed.

It seems that the conditions of climate securitization at the international level have not yet been met. China and other developing countries' positions suggest that the receptivity of various members of the climate security audience has been determined not only by how convincing they found the case to be that climate change threatens security, but also by consideration of what the international legal and institutional ramifications of accepting that would be (Scott 2012). The involvement of UNSC as the potential outcome of international climate securitization makes China and other developing countries' worry that their domestic affairs might be interfered with and national sovereignty infringed on.

There are also equity concerns that must not be ignored. A shift to climate conflict discourse and the involvement of UNSC may lead to narrower policy options in a way that privileges the interests of those who are already powerful over those who are already disadvantaged (Parks and Roberts 2006). This would not be helpful to the primary victims of climate change. For many developing countries, shifting climate decision making to the Security Council could jeopardize their ability to promote their interests in getting resources for climate adaptation and mitigation projects from developed states.

The effectiveness of climate securitization is not so high if not counterproductive. So far, the debates on the role of UNSC have not advanced international (national) efforts to address climate change substantially. The securitization of climate change has not broken through the political stalemate that characterizes the multilateral treaty-making process by raising the threat in a visible sense. Moreover, the introduction of conflict concerns into the UNSC debate has created tensions, particularly around the question of whether the Security Council should play a role in developing the global response to climate change.

At the domestic level, China's climate change policy reflects that it frames climate change primarily as a development issue with increasing security implications. In other words, climate change is both a development and a security issue in China and the two speech acts coexist in a more recent context. Although China has input more momentum to the securitization of climate change in both academia and government, it seems that there is a disjuncture between labeling climate change as a nontraditional security issue and emergency measures. China's broad policy options, including mitigation and adaptation straggles as well as the military's more active but limited involvement contribute to its enhanced urgency of taking effective action in climate change. 
Compared with their divergence on whether the Security Council should play a role in developing global response to climate change, the EU and China have responded to climate security with a converging trend in terms of mitigation. Both agree that serious mitigation efforts are required to tackle climate change and have adopted a number of policies to this end. Both jurisdictions have submitted their Intended Nationally Determined Contributions to the UNFCCC secretariat, setting mitigation targets for the year 2030. In some policy areas, such as GHG emissions trading systems, convergence can be observed. Moreover, compared with the political hurdle of climate securitization at the international level, the newly adopted global climate agreement in Paris further indicates world faith in UNFCCC processes since it offers more balanced elements of climate governance for post2020, including long-term goals, pledges to curb emissions, loss and damage etc.

Lastly, the securitization framework draws attention to the role of language in constructing security and suggests that the successful construction of an issue as a security threat enables emergency measures to deal with that issue. However, the security discourse could not be constructed without certain political background or actors, as the above shows. The construction of security through language is important but securitization theory could have practical significance only when its dependence on the speech act theory is combined with action ability.

Acknowledgments Funding source: Chinese Ministry of Education Designated Research Program 2015 (Project Number 15JZD035).

\section{References}

Balzacq, T. 2005. The three faces of securitization: Political agency, audience and context. European Journal of International Relations 11: 171-201.

Balzacq, T. (ed.). 2010. Securitization theory. London: Routledge.

Barnett, Jon, and W. Neil Adger. 2007. Climate change, human security and violent conflict. Political Geography 26: 639-655.

Buzan, B., O. Wæver, and J. de Wilde. 1998. Security: A new framework for analysis. Boulder, CO: Lynne Rienner.

Buzan, B., O. Wæver, and J. de Wilde. 2008. Security: A New Framework for Analysis. Lynne Rienner.

Caballero-Anthony, M., Ralf Emmers, and Amitav Acharya, ed. 2006. Non-traditional security in Asia: Dilemmas in securitization. UK: Ashgate.

Detraz, N., and Michele M. Betsill. 2009. Climate change and environmental security: for whom the discourse shifts. International Studies Perspectives 2009(10): 303-320.

Dupont, A. 2008. The strategic implications of climate change. Survival 50(3): 29-54.

Fanoulis, E., and Emil Kirchner. 2015. "Nontraditional Security Issues". In China, the European Union, and the International Politics of Global Governance, eds. Wang Jianwei and Song Weiqing. Canada: Palgrave.

Freeman D. 2010. The missing link: China, climate change and national security. Asia Papers 5(8). Brussels Institute for Contemporary China Studies. http://www.vub.ac.be/biccs/site/assets/files/ apapers/Asia\%20papers/201012\%20.

Gad, U., and K. Petersen. 2011. Concepts of politics in securitization studies. Security Dialogue 42: $315-328$.

Hu, Jintao. (2012). Firmly march on the path of socialism with Chinese characteristics and strive to complete the building of a moderately prosperous society in all respects. A report at the 18th National Congress of the CPC (November 8, 2012). http://www.chinaembassy-org.be/eng/sghd/ t990697.htm. 
Information Office of the State Council of the People's Republic of China (PRC). 2007. China's National Climate Change Program.

Information Office of the State Council of the People's Republic of China (PRC). 2008. China's Policies and Actions for Addressing Climate Change.

Information Office of the State Council of the People's Republic of China (PRC). 2009. China's National Defense in 2008.

Information Office of the State Council of the People's Republic of China (PRC). 2011. China's National Defense in 2010.

Li, L.P. 2009. Military and Non-traditional security. Beijing: Shishi Press.

Liotta, P.H., and Allan W. Shearer. 2007. Gaia's revenge: Climate change and humanity's loss. Westport: Praeger Publishers.

Mazo, J. 2010. Climate conflict. London: Routledge.

McDonald, M. 2008. Securitization and the construction of security. European Journal of International Relations 14: 563-587.

Mcdonald, M. 2012. The failed securitization of climate change in Australia. Australian Journal of Political Science 47(4): 579-592.

NDRC. 2009. China's policies and actions for addressing climate change: The progress report.

NDRC. 2013. China's policies and actions for addressing climate change.

Parks, B.C., and J. Timmons Roberts. 2006. Environmental and ecological justice. In Palgrave Advances in International Evironmental Politics, eds. Michele M. Betsill, Kathryn Hochstetler, and Dimitris Stevis. New York: Palgrave.

Purvis, Nigel, and Joshua Busby. 2004. The security implications of climate change for the UN system. Environmental Change and Security Program Report 10: 67-73.

Roe, P. 2008. Actor, audiences and emergency measures. Security Dialogue 39: 615-635.

Salter, M. 2010. When securitization fails: the hard case of counter-terrorism programs. In Securitization Theory, ed. T. Balzacq. London: Routledge.

Scott, S. 2012. The securitization of climate change in world politics: How close have we come and would full securitization enhance the efficacy of Global climate policy? RECIEL 21(3).

Stritzel, H. 2007. Towards a theory of securitization: Copenhagen and beyond. European Journal of International Relations 13: 357-384.

Wæver, O. 1995. Securitization and desecuritization. In On security, ed. R.D. Lipschutz. New York: Columbia University Press.

Wæver, O. 2007. Climate change: The security issue of the future? Politics and International Studies Seminar Series. Warwick: University of Warwick.

Zhang, H.B. 2010. Climate change and China's National Security. Beijing: Shishi Press.

Zhang, H.B. 2015. The Impact of Climate change On Chinese National Security: The perspective of Comprehensive National Security, Quarterly Journal of International Politics, 4.

Zheng, G.G. 2014a. To maintain climate security and assure ecological security. People's Daily.

Zheng, G.G. 2014b. To cognize climate change scientifically and pay high attention to climate security. People's Daily.

Zheng, G.G. 2015. To cognize climate change scientifically and pay close attention to climate security. Remarks on World Meteorological Day. People's Daily.

Yan Bo is Professor in School of International Relations and Public Affairs, Fudan University. Her major publications in Chinese include: The Trilateral Relations among China, the US, the EU in Global Climate Governance (2012); International Negotiations and Domestic Politics: the Case of the US and Kyoto Protocol (2007); 'The Divergence between China and the EU on the 2015 Global Climate Agreement', in Modern International Relations (Beijing), 2014. She is also the first author of “The EU's Engagement with China in Global Climate Governance", in Bouchard, Caroline et al. (eds) Multilateralism in the 21st Century: Europe's Quest for Effectiveness, Routledge, 2013. 